\title{
Fish population responses to hydrological variation in a seasonal wetland in southeast México
}

\author{
Luis H. Escalera-Vázquez ${ }^{1}$, Nancy Calderón-Cortés² and Luis Zambrano-González ${ }^{3}$
}

Hydrological variation differently affects fish species. In the present study, the response of local populations of 13 fish local species to hydrological variation in a tropical wetland was evaluated. The objectives were to analyze the abundance response of fish species with distinct life history strategies and to assess the role of hydrological variation on fish population patterns. We found that opportunistic strategists were favored by high hydrological variation in drought periods, the equilibrium strategists were related to stable habitats, and periodic strategists were regulated by floods and temperature. However, the life history strategies identified for some species in this study do not correspond to the classification reported in other studies. Our results highlight the importance to study the abundance responses of species at local and regional scales to identify variations in life-history strategies, which can reflect local adaptations of species to hydrological changes, this is useful in order to understand and predict the responses of fish populations to the local environment.

Key words: Dry season, Fish resilience, Life history strategies, Rainy season, Sian Ka'an.

La variación hidrológica afecta de manera diferencial a las especies de peces. En el presente estudio, se evaluó la respuesta de las poblaciones locales de 13 especies de peces considerando la variación hídrica en un humedal tropical. Los objetivos fueron analizar la respuesta de las abundancias de las especies de peces con diferentes estrategias de historia de vida e identificar la importancia de la variación hídrica en los patrones de las poblaciones de peces. Se encontró que los estrategas oportunistas fueron favorecidos por la alta variación hídrica en los periodos de sequía, los estrategas de equilibrio se relacionaron con hábitats estables, y que los estrategas periódicos son regulados por las inundaciones y la temperatura. Sin embargo, para algunas especies las estrategias de historias de vida identificadas en este estudio no corresponden a la clasificación reportada en otros estudios. Nuestros resultados resaltan la importancia de estudiar las respuestas de la abundancia de las especies a escalas locales y regionales para identificar las variaciones en las estrategias de historia de vida, las cuales pueden reflejar adaptaciones locales de las especies a cambios hídricos, esto es útil para entender y predecir las repuestas de las poblaciones de peces a los ambientes locales.

Palabras clave: Capacidad de recuperación, Estación seca, Estrategias de historia de vida, Sian Ka'an, Temporada de lluvias.

\section{Introduction}

The hydrological regime is of central importance in sustaining the ecological processes in flowing and flooding water systems, because it promotes environmental fluctuations that affect populations of species and communities (Richter et al., 1996; Poff et al., 1997; Coops et al., 2003). Periodic hydrological variation in rivers and wetlands plays a significant role in generating responses for various biological attributes such as gonad maturation, migration, recruitment, growth and feeding (Winemiller, 1989; Gomes, Agostinho, 1997; Taylor et al., 2001;
Agostinho et al., 2004; Lytle, Poff, 2004; DeAngelis et al., 2010; Hinojosa-Garro et al., 2013). The hydrological regime can fluctuate on different time scales (from days to decades) depending on regional climatic conditions (Poff et al., 1997; Coops et al., 2003). In general, wetlands are characterized by a seasonal variation in hydrological conditions, showing periodic drying and flooding events (Mitsch et al., 2009).

Water level variation in wetlands can cause high fish mortality in dry periods (DeAngelis et al., 1997; Kobza et al., 2004), but in wet seasons floods promote pulses of nutrients and reproductive events (Poff et al., 1997; Agostinho et al., 2004). Thus, in these ecosystems, water level fluctuations

${ }^{1}$ CONACYT - Instituto de Investigaciones sobre los Recursos Naturales, Universidad Michoacana de San Nicolás de Hidalgo. Avenida Juanito Itzicuaro SN, Nueva Esperanza, 58330 Morelia Michoacán, México. lhescalera@gmail.com (corresponding author)

${ }^{2}$ Escuela Nacional de Estudios Superiores Unidad Morelia, Universidad Nacional Autónoma de México, Antigua Carretera a Pátzcuaro 8701, Ex-Hacienda de San José de La Huerta, 58190 Morelia, Michoacán, México. ncalderon@enesmorelia.unam.mx

${ }^{3}$ Departamento de Zoología, Instituto de Biología, Universidad Nacional Autónoma de México. Ciudad Universitaria, 04510 Ciudad de México, México.zambrano@ib.unam.mx 
influence death and birth rates of the species, causing variation of natural populations over time (DeAngelis et al., 1997, 2005; Ruetz et al., 2005). However, fish species inhabiting these ecosystems possess different functional traits such as body size, fecundity, duration of reproduction, and longevity that can influence the demographic parameters (Winemiller, 1989, 2005; Winemiller, Rose, 1992). Based on these functional traits, three life history strategies are recognized for freshwater and marine fishes: (i) opportunistic (short generation time, high reproductive effort, small body size, low batch fecundity, and low investment per offspring); (ii) periodic (long generation time, moderate reproductive effort, large body size, high batch fecundity, and low investment per offspring); and (iii) equilibrium (moderate to long generation time, low reproductive effort, variable body size, low batch fecundity (Winemiller, 1989, 2005; Winemiller, Rose, 1992; Rose, Cowan, 2000). Convergence in these three life history strategies has been recognized for Neotropical, North American and European freshwater fish (Winemiller, 1989; Vila-Gispert et al., 2002; Blanck, Lamouroux, 2007; Mims et al., 2010), and North American marine fish (Winemiller, Rose, 1992), as well as for fish communities in different latitudinal and hydrological gradients (Lamouroux et al., 2002; Tedesco, Huguery, 2006; Tedesco et al., 2008; Mims et al., 2010; Olden, Kennard, 2010). These studies emphasize the differences of fish responses to hydrological variation based on their life history strategies: periodic strategies are favored in highly seasonal drainage basins, the equilibrium strategies in hydrologically stable drainage basins, and the opportunistic strategies in habitats with high hydrologic variability (DeAngelis et al., 1997, 2005, 2010; Winemiller, 1989, 2005; King et al., 2003; Tedesco, Huguery, 2006; Blanck, Lamouroux, 2007; Tedesco et al., 2008; Olden, Kennard, 2010), but only few studies have empirically tested these predictions (Blanck et al., 2007; Mims, Olden, 2012).

Fish population responses to hydrological regime have been extensively studied in rivers (e.g. Franssen et al., 2006; Gubiani et al., 2007; Magalhaes et al., 2007). However, wetlands have been less studied (DeAngelis et al., 1997, 2010; Ruetz et al., 2005). Understanding the role of hydrological variation in ecosystem functioning has become even more crucial with current concerns about global climate change that predict an increase of interannual variability (Coops et al., 2003; Wantzen et al., 2008). Thus, reference data on tropical wetlands exhibiting natural hydrological variation are necessary for future evaluations of the impact of climate change on these ecosystems.

The Reserva de la Biósfera de Sian Ka'an presents a matrix of seasonal freshwater wetlands, located near to the coast in Quintana Roo, México. In this region, the topography generates small permanent pools, which are potential refuges for fish in dry periods. Although close to a development for Cancún-Tulum tourism, the reserve presents a large area free of anthropogenic perturbations and non-native species, and the hydrologic regime has remained unmodified (Zambrano et al., 2006). The fish species in these wetlands exhibit different life history strategies: equilibrium, periodic and opportunistic (Winemiller, 1989, 2005; Winemiller, Rose, 1992). Therefore, the pristine and dynamical characteristics of the system, and the diversity of life history strategies of fish species, offers the opportunity to understand population dynamics and responses of fish species to hydrological variation, particularly to extreme changes in flood and dry periods.

In this study, the response of local populations of 13 fish species to hydrological variation in a tropical wetland was examined. Several species exhibiting different life history traits were studied to evaluate if their responses differ among fish strategies. The objectives were: (1) to analyze the abundance response of fish species with distinct life history strategies; and (2) to assess the role of hydrological variation on fish population patterns. We hypothesized that: (1) fish species within the same life history strategy will show the same response to the hydrological fluctuations; and (2) hydrological fluctuations and environmental variables related with the hydrology will affect species with distinct life strategies differently. Specifically, we expected that high hydrological variation in drought periods favors the opportunistic strategists and negatively affects the equilibrium strategists, while seasonal variability in flood favors the periodic strategists.

\section{Materials and Methods}

Study area. The Reserva de la Biósfera de Sian Ka'an (RBSK; $528.47 \mathrm{~km}^{2}$ ) is located along the east central coast of the Yucatán peninsula in southeastern Mexico (Fig. 1). The hydrologic dynamics and topography of the RBSK generate a matrix of wetlands. During the dry season, most of the water bodies are reduced and isolated. Therefore, this system offers the opportunity to understand changes in fish populations according to the hydrologic regime. The wetland at the RBSK reached their maximum annual water level at the end of the wet season (February-March). Water levels decline substantially during the short dry season (March-April). This wetland comprises small permanent pools surrounded by tree islands known as petenes in a flooded marsh matrix of sawgrass (Cladium jamaicense Crantz), gulfcoast spikerush (Eleocharis cellulose Torr.) and cattail (Typha dominguensisis Pers.), where numerous temporary pools are also present. Permanent pools are oligotrophic, surrounded by palms (Acoelorraphe wrightii Griseb., H. Wendl.) and swamp hardwoods, common reed (Phragmites australis Cav.), and in some cases jicaco trees (Chysobalanus icaco L.). Temporary pools are surrounded by sawgrass and gulfcoast spikerush. In a previous study, 13 continental freshwater fish species were recorded from this wetland (Escalera-Vázquez, Zambrano, 2010), with the most representative fish families in this area being Cichlidae, Poecilidae, Characidae, Cynolebiidae, Pimelodidae and Symbranchidae. 


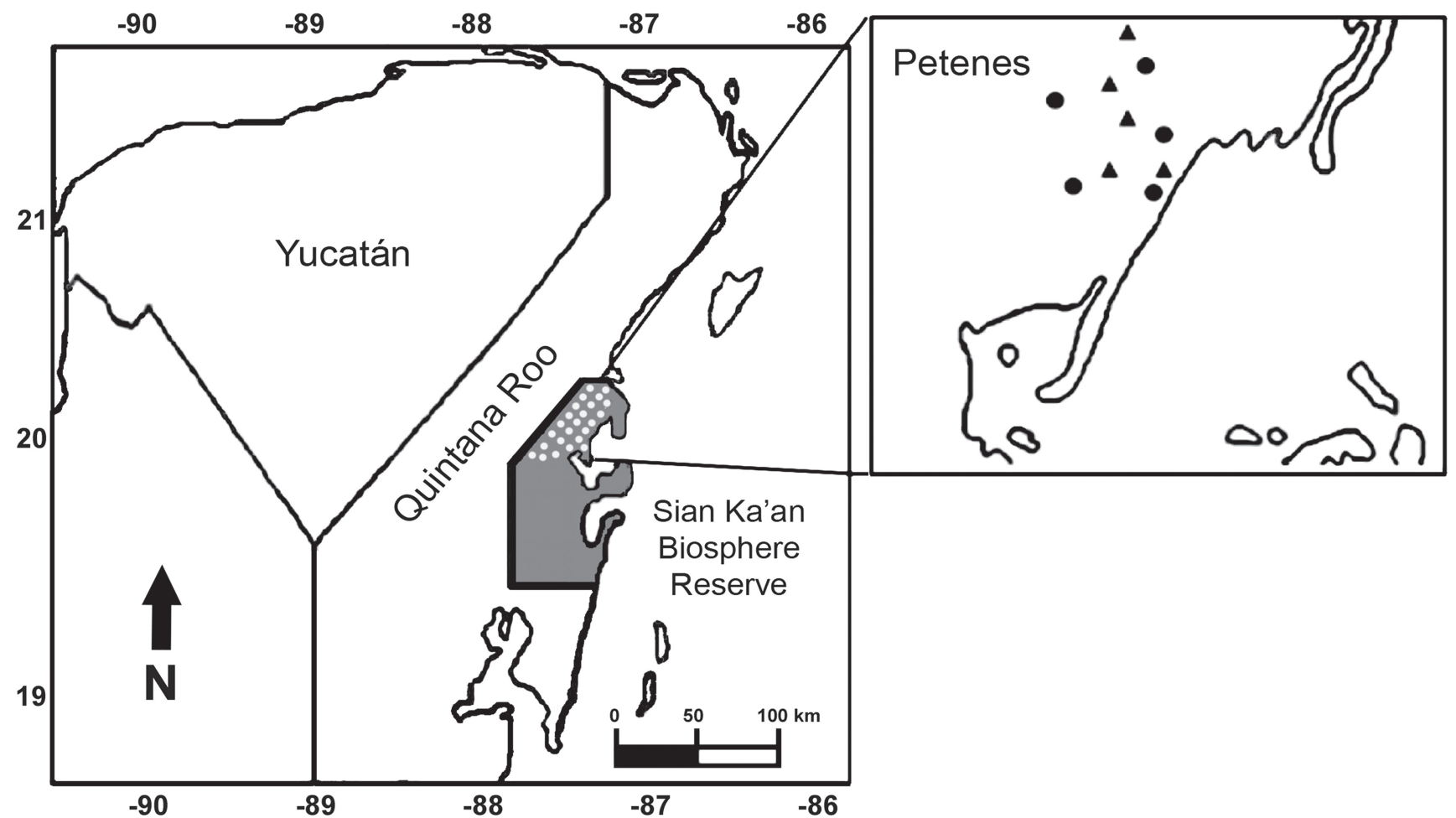

Fig. 1. Map of the study site in the Sian Ka' an wetland. Triangles = temporary pools; circles = permanent pools.

The fish species in this wetland are classified into three general life history strategies: equilibrium, periodic and opportunistic (Winemiller, 1989, 2005; Winemiller, Rose, 1992). According to this classification, yellowjacket cichlid Parachromis friedrichsthalii (Haeckel, 1840), jack dempsey Rocio octofasciata (Regan, 1903), firemouth cichlid Thorichthys meeki Brind, 1918, mayan cichlid Mayaheros urophthalmus (Günther, 1862), and swamp eel Ophisternon aenigmaticum Rosen, Geenwoog, 1976 exhibit an equilibrium strategy (Winemiller, 1989; Winemiller, Rose, 1992); whereas banded tetra Astyanax aeneus (Günther, 1860), silver catfish Rhamdia guatemalensis (Günther, 1864), and maya rivulus Cynodonichthys tenuis (Meek, 1904) show a periodic strategy (Winemiller, 1989; Winemiller, Rose, 1992). Finally, southern platyfish Xiphophorus maculatus (Günter, 1866), twospot livebearer Pseudoxiphophorus bimaculatus (Heckel, 1948), mangrove molly Poecilia orri Fowler, 1943, shortfin molly $P$. mexicana Steindachner, 1863 and teardrop mosquito Gambusia sexradiata Hubbs, 1936 belongs to the opportunistic strategy (Winemiller, 1989; Winemiller, Rose, 1992)

Sampling was carried out in dry season (April), warm rainy season (August), and cold rainy season with storms and winds known as "nortes" (January) during three consecutive years (from April 2007 to January 2010). We selected five permanent and five temporary pools located near each other, such that they were interconnected during a wet season. Pools were characterized measuring mean depth and area. We monitored daily water level and temperature deploying a data logger (HOBO; Onset Computer Corporation, Bourne, MA, U.S.A.) in all pools.
Fish sampling and environmental data. Gee ${ }^{\circledR}$ minnow traps $(2 \mathrm{~mm}$ mesh, funnel entrance diameter of $20 \mathrm{~mm}$, central diameter of $19 \mathrm{~cm}$, external diameter of $12 \mathrm{~cm}$ and total length of $41.9 \mathrm{~cm}$ ) were used to catch fish. According to Kobza et al. (2004), these traps are the best method for sampling fish in small water bodies with complex dimensions and irregular edges. We set one minnow trap in each pool for 24 hours with the top of the trap 7-10 mm above the water surface to prevent fish mortality from low oxygen levels at night. The abundance of fish each species was recorded, and each fish captured was measured in situ to the nearest $0.01 \mathrm{~mm}$ using a digital calliper (Tresna ${ }^{\circledR}$ EC16; Trensnainstrument); after these measures fishes were released. The average of fish catch-per-unit-effort (CPUE) along the sampling period for each pool was used for comparisons. CPUE is a measure of encounter rate of the traps by fish and is determined by the movement rate and density of fish (Obaza et al., 2011). By assuming that fish movement rate is roughly constant, we can interpret comparisons over time and space as indicative of changing fish abundance. We used common and scientific names of identified fishes following Greenfield, Thomerson (1997) and Nelson et al. (2004).

Data analysis. To examine the response of fish populations to hydrological variation, duration of flood and dry periods preceding each sampling event were estimated. Duration of flood was defined as the number of days in which water level was $>50 \mathrm{~cm}$ for the temporary pools in the floodplain, and $50 \mathrm{~cm}$ above the maximum depth of 
each permanent pool. An increase of $50 \mathrm{~cm}$ in the water level in this system ensures that all pools are connected. Duration of dry periods was defined as the number of days in which water level was $<10 \mathrm{~cm}$ for temporary pools, because at this water level fish are trapped in organic material (i.e. periphyton). In the case of permanent pools, duration of dry periods was estimated as the number of days that the water level remained with $<$ half of their maximum depth.

Time series analyses were performed using a mixed linear model (based on maximum likelihood) to test for differences in hydrological variation (duration of flood and dry periods) among habitats, seasons, years, and the interaction between season and year. Covariance structure was modeled as first-order autoregressive process, because this covariance structure showed the best fit (Littell et al., 1996). Site was used as the random subject factor. This analysis was performed in SAS software version 9.2 (SAS Institute, Cary, NC, U.S.A.).

To elucidate if species with the same life history strategy show the same response to the hydrological predictors, we classified the species into "opportunistic", "equilibrium" and "periodic" based on Winemiller (1989, 2005) and Winemiller, Rose (1992) and performed a Canonical Redundancy Analysis (RDA). This technique selects the linear combination of environmental data with the smallest total residual sum of squares (Ter Braak, Verdonschot, 1995). Abundance of each species was transformed based on Hellinger distance (Legendre, Gallagher, 2001). To evaluate the model's performance and significance of constraints, an analysis of variance (ANOVA) was performed based on 1000 permutation tests (Legendre, Legendre, 1998; Legendre, Gallagher, 2001). The statistical analyses were carried out in R 3.0.2 (R Development Core Team, 2014) using the packages vegan (Oksanen et al., 2013).

\section{Results}

The analysis of hydrological variation showed that habitat, year, season and the interaction between season and year had a significant effect on depth, temperature, the number of flooded and the number of dry days, with exception of season that did not show a significant effect on the number of dry days (Tab. 1). However, the number of dry days was lower in permanent pools than in temporary pools (Fig. 2). According to our data, 2008 and 2009 were the driest years and exhibited a lower number of flooded days. The pattern in the temporal variation in temperature was similar for both types of pools, but from 2007 to 2008 higher temperatures were obtained for temporary pools, which were affected by a long period of dry days producing a gap in temperature in 2009 in the dry and warm rainy seasons because pools dried. Depth showed similar temporal patterns for both types of pools. However, permanent pools were deeper than temporary pools.
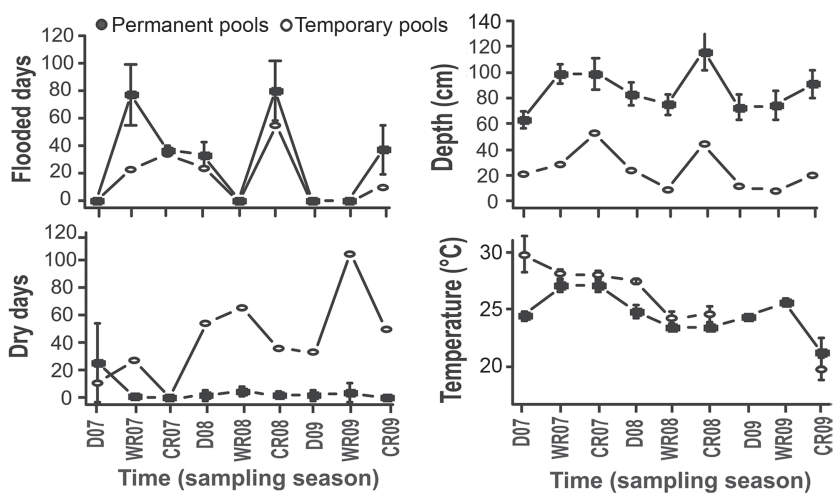

Fig. 2. Hydrological regime (percentage in days) in permanent (PP) and temporary pools (TP) in the Sian Ka'an wetland. Error bars represent \pm 1 S.E. Least-squares means and standard errors were estimated based on the mixed linear model. Permanent pools did not present dry days, and are not showed in the upper plot. $\mathrm{X}$ axis represents sampling seasons $(\mathrm{D}=\mathrm{Dry}, \mathrm{WR}=$ Warm rainy, and $\mathrm{CR}=$ Cold rain $)$ and years $(07=2007,08=2008$, and $09=2009)$.

Tab. 1. Mixed Linear Model to test for interannual and seasonal differences related to hydrological parameters. $\mathrm{df}=$ degrees of freedom, $\mathrm{F}=\mathrm{F}$-value, $\mathrm{P}=\mathrm{P}$-value, asterisk = interaction.

\begin{tabular}{|c|c|c|c|c|c|}
\hline & & Flooded days & Dry days & Depth & Temperature \\
\hline \multirow{3}{*}{ Habitat } & $\mathrm{df}$ & 1,67 & 1,67 & 1,67 & 1,67 \\
\hline & $\mathrm{F}$ & 38.67 & 62.76 & 461.43 & 28.96 \\
\hline & $\mathrm{P}$ & $<0.001$ & $<0.001$ & $<0.001$ & $<0.001$ \\
\hline \multirow{3}{*}{ Year } & $\mathrm{df}$ & 2,67 & 2,67 & 2,67 & 2,67 \\
\hline & $\mathrm{F}$ & 29.23 & 8.79 & 13.67 & 68.67 \\
\hline & $\mathrm{P}$ & $<0.001$ & 0.004 & $<0.001$ & $<0.001$ \\
\hline \multirow{3}{*}{ Season } & $\mathrm{df}$ & 2,67 & 2,67 & 2,67 & 2,67 \\
\hline & $\mathrm{F}$ & 64.76 & 1.94 & 66.53 & 28.33 \\
\hline & $\mathrm{P}$ & $<0.001$ & 0.1519 & $<0.001$ & $<0.001$ \\
\hline \multirow{3}{*}{ Season*year } & $\mathrm{df}$ & 4,67 & 4,67 & 4,67 & 4,67 \\
\hline & $\mathrm{F}$ & 30.33 & 3.45 & 11.62 & 22.38 \\
\hline & $\mathrm{P}$ & $<0.001$ & 0.012 & $<0.001$ & $<0.001$ \\
\hline
\end{tabular}

A total of 3981 individuals belonging to 13 species were captured, among these, A. aeneus, G. sexradiata, $P$. bimaculatus and $X$. maculatus were the species that showed the highest abundance across years and seasons. These species also showed difference in abundance between habitats; $A$. aeneus, P. bimaculatus and $X$. maculatus were more abundant in permanent pools, and G. sexradiata was more abundant in temporary pools. The species with low abundances were $M$. urophthalmus. P. mexicana, $C$. tenuis and $O$. aenigmaticum, and they showed low variation in abundance over time and between habitats. P. friedrichsthalii, T. meeki, R. octofasciata, $R$. guatemalensis and $P$. orri were present in both habitats with moderate abundances. The temporal pattern in species richness was similar for both types of pools over time, but as mentioned above there were not temporary pools for the dry and warm rainy season in 2009 (Fig. 3; S1 - Available only as online supplementary file accessed with the online version of the article at http://www.scielo.br/ni). 


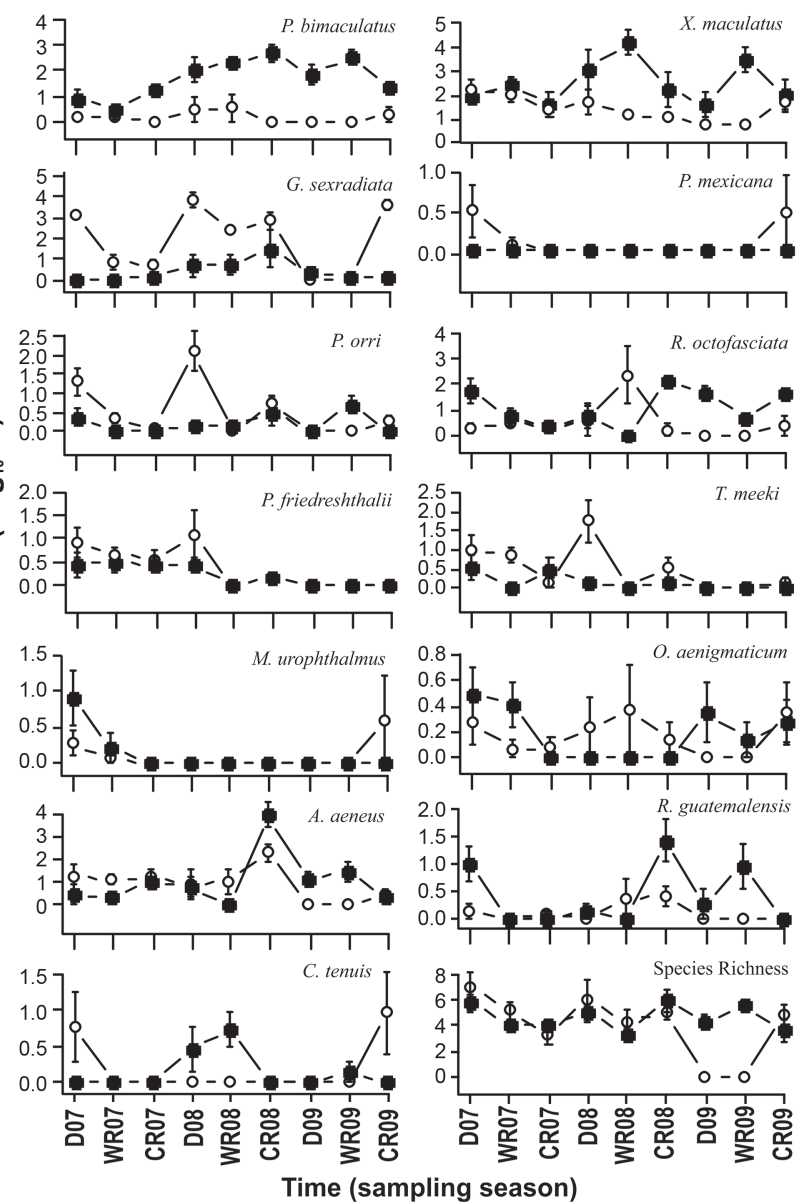

Fig. 3. Fish population patterns in permanent (PP) and temporary pools (TP) over time. The three sampling periods within years describe general seasonal patterns. Error bars represent \pm 1 S.E. $X$-axis represents sampling seasons $(\mathrm{D}=$ Dry, $\mathrm{WR}=$ Warm rainy, and $\mathrm{CR}=$ Cold rain $)$ and years $(07$ $=2007,08=2008$, and $09=2009$ ).

The RDA model revealed the relationship between the abundance of species and the hydrological variables (Fig. 4). The combined effect of the first two canonical axes explained $91.71 \%$ of the total variance of the data, and the first axis alone accounts for $76.49 \%$ of the variance. The first two speciesenvironment-correlations were 0.84 and 0.62 (Tab. 2). The significant hydrological variables in the RDA model were the number of flooded days, depth and temperature, but depth was the variable with the highest correlation for axis 1 , while temperature and number of flooded days showed high correlation values for axis 2 (Tab. 2). The first axis represents a spatial gradient from deeper (left) to shallow pools (right), distinguishing the temporary and permanent pools present in the studied wetland (Fig. 4a). This axis also plays an important role in the dispersion of species along this depth gradient (Fig. 4b), in which three groups can be identified: i) species in deeper pools ( $X$. maculatus and P. bimaculatus), ii) species clustered near the center of the RDA diagram $(P$. mexicana, $P$. orri, $P$. friedrichsthalii, $M$. urophthalmus, $R$. octofasciata, T. meeki, O. aenigmaticum, $R$. guatemalensis,
A. aeneus and $C$. tenuis), and iii) one species in shallow pools ( $G$. sexradiata). However, the axis 2 indicates that temperature and the number of flooded days separate the species near the center in two groups, one related to warmer pools and higher number of flooded days (A. aeneus, $P$. friedrichsthalii and T. meeki), and the other one showing none to low negative correlation to these variables (P. mexicana, $P$. orri, M. urophthalmus, $R$. octofasciata, $O$. aenigmaticum, $R$. guatemalensis and C. tenuis). Opportunistic and equilibrium strategies are dispersed along the RDA axis 1, while the periodic strategists are dispersed along the RDA axis 2 .

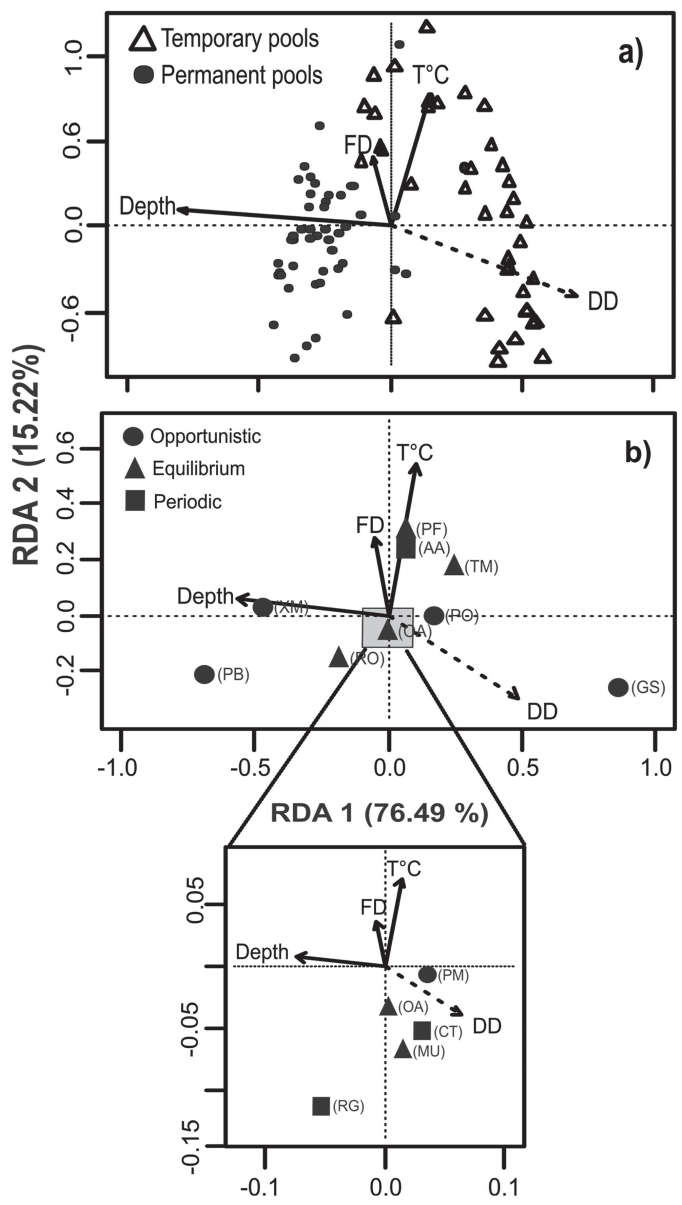

Fig. 4. Redundancy analysis (RDA) biplot of sites scores (a) and species scores (b) for fish species recorded in the Sian $\mathrm{Ka}$ 'an wetland regarding the life history strategy; lower panel represents a close up from the center of the RDA diagram in order to illustrate tightly grouped species. Arrows point in the direction of maximum variability explained by the respective environmental variable; dashed arrow represents nosignificant variables in the RDA model. The fish species names are represented in parentheses: $\mathrm{GS}=$ Gambusia sexradiata, $\mathrm{PM}$ $=$ Poecilia mexicana, $\mathrm{PB}=$ Pseudoxiphophorus bimaculatus, $\mathrm{XM}=$ Xiphophorus maculatus, $\mathrm{PO}=$ Poecilia orri, $\mathrm{TM}=$ Thorichthys meeki, MU = Mayaheros urophthalmus, $\mathrm{PF}=$ Parachromis friedrichsthalii, $\mathrm{RO}=$ Rocio octofasciata, $\mathrm{RG}=$ Rhamdia guatemalensis, $\mathrm{CT}=$ Cynodonichthys tenuis, $\mathrm{AA}=$ Astyanax aeneus, $\mathrm{OA}=$ Ophisternon aenigmaticum. 
Tab. 2. Summary of redundancy analysis. Asterisks denotes significant variables $(p<0.05)$ in de RDA model based on 1000 permutations.

\begin{tabular}{ccccc}
\hline \multirow{2}{*}{$\begin{array}{c}\text { Species-environment } \\
\text { correlations }\end{array}$} & 1 & 2 & 3 & 4 \\
\cline { 2 - 5 } & 0.84 & 0.62 & 0.32 & 0.26 \\
\hline & \multicolumn{2}{c}{ Canonical coefficient } & \multicolumn{2}{c}{ Inter-set correlation } \\
\cline { 2 - 5 } & \multicolumn{2}{c}{ Axis 1 } & Axis 2 & \multicolumn{2}{c}{ Axis 1 } & Axis 2 \\
\hline Flooded days* & -0.08 & 0.50 & -0.07 & 0.31 \\
Dry days & 0.77 & -0.49 & 0.65 & -0.30 \\
Depth* & -0.89 & 0.15 & -0.75 & 0.09 \\
CV (depth) & -0.69 & 0.00 & -0.58 & 0.00 \\
Temperature* & 0.17 & 0.82 & 0.15 & 0.51 \\
\hline
\end{tabular}

\section{Discussion}

According to our hypothesis we found different responses among fish species. When species are ordered simultaneously on the two primary axes of RDA, a continuum of fish abundance responses are identified across three endpoints (Fig. 4): i) one species highly abundant in shallow temporary pools exposed to long dry periods; ii) a group of two species with high abundances in deeper and more stable permanent pools less exposed to drying events; and iii) a group of three species associated mainly to warmer temporary pools exposed to high seasonality of floods. This association of species responses are in congruence with the three life history strategies (i.e. opportunistic, periodic and equilibrium) proposed by Winemiller $(1989,2005)$ and Winemiller, Rose (1992) for Neotropical and North American freshwater fish. Our results in the continuum of abundance responses indicated that $G$. sexradiata (Poeciliidae) represents the opportunistic strategy favored by high hydrological variation in drought periods, since populations of opportunistic fish can recover rapidly from dry periods that kill large numbers of organisms, and maintain large populations in the face of high mortality in the adult stage (Winemiller, 1989, 2005; Winemiller, Rose, 1992; Rose, Cowan, 2000); X. maculatus and $P$. bimaculatus (Poeciliidae) represent the equilibrium strategies, which occur in stable and less seasonal habitats (Winemiller, 1989; Rose, Cowan, 2000; Mims, Olden, 2012); whereas A. aeneus (Characidae), T. meeki (Cichlidae) and P. friedrichsthalii (Cichlidae) represent the periodic strategy, which have seasonally fluctuating populations mainly regulated by flooding events (Winemiller, 2005; Mims, Olden, 2012). However, for some species (X. maculatus, P. bimaculatus, T. meeki and $P$. friedrichsthalii) the life history strategies identified in this study do not correspond to the classification originally proposed by Winemiller (1989) and Winemiller, Rose (1992), since they classified the family Poeciliidae as opportunistic and Cichlidae as equilibrium strategists. In addition, we found a fourth group of intermediate species at the boundaries of equilibrium and periodic strategies including P. mexicana (Poeciliidae), P. orri (Poeciliidae), M. urophthalmus (Cichlidae), R. octofasciata (Cichlidae),
$O$. aenigmaticum (Synbranchidae), $R$. guatemalensis (Pimelodidae) and C. tenuis (Cynolebiidae), associated either to temporary and permanent pools, with low abundances and low relationships to seasonal variation. Similarly, previous studies have shown differences in the ordination of species among populations of the same species within the life history space (Vila-Gispert et al., 2002; Blanck et al., 2007). This lack of consistence in the classification of some species may be explained by differences in habitat preference, abiotic tolerances, migration ability, phenotypic plasticity, and intraspecific variation in life history functional traits (DeAngelis et al., 1997; Rochet, 2000; Vila-Gispert et al., 2002; Blanck et al., 2007; Blanck, Lamouroux, 2007; Magalhaes et al., 2007).

Poecilidae is a family of freshwater fish that includes rapid colonizers that tolerate a wide variety of habitats and feed on areas near vegetated shorelines where their food (i.e. benthic invertebrates and insects) is abundant (Greenfield, Thomerson, 1997; Miller, 2005; Ruetz et al., 2005). Species in this family generally show preferences for habitats subjected to high hydrological variation and/ or harsh environments, such as shallow marginal areas of larger water bodies and small-shallow waterbodies (Meffe, Snelson, 1989) usually associated to opportunistic species, as is the case of Gambusia spp. (Meffe, Snelson, 1989; DeAngelis et al., 2005; Escalera-Vázquez, Zambrano, 2010). However, X. maculatus and P. bimaculatus have been reported in deep habitats $(>1 \mathrm{~m})$ with dense canopy of trees and shaded areas (Miller, 2005). This suggests that some species in the Poeciliidae family might show different responses to the hydrological variation to those expected for opportunistic species, as was the case of $X$. maculatus and P. bimaculatus which responded according to the equilibrium strategists associated to permanent pools in the RBSK wetland.

On the other hand, even though most of the species belonging to the Cichlidae family are associated to deep waterbodies such as streams, rivers, lagoons and lakes (and hence to equilibrium strategies), some species (particularly neotropical cichlids) prefer other habitats such as pools, floodplains, lowlands and adjacent highlands that can experienced hydrological variability (Miller, 2005; Cochran-Biederman, Winemiller, 2010), or show seasonality in habitat selection for breeding and nursery (McKaye, 1980). Given that floods occupy large areas of the terrestrial environment (floodplain) of water bodies and promote pulses of nutrients from decomposition of inundated floodplain vegetation, providing important resources and nursery grounds for fish (Richter et al., 1996; Poff et al., 1997; Agostinho et al., 2004), it is possible that cichlids with seasonal movements among deep and shallow habitats show an abundance response more related to periodic than equilibrium strategists, as we found for T. meeki and P. friedrichsthalii. The same can be applied to those intermediate species in the RBSK wetland 
in the continuum of equilibrium-periodic strategies, which can have seasonal movements between temporary and permanent pools, such as $R$. guatemalensis, a predator fish that might have seasonal movements in response to the availability of preys (Miller, 2005).

Interestingly, despite the differences in habitat preference among species in the studied wetland, all species can be present in one time or another in permanent pools, suggesting that permanent pools function as refuges in dry periods. Refuges for fish are one of the factors helping to mitigate the severity of the effects of dry periods (DeAngelis et al., 1997, 2010; Magoulick, Kobza, 2003; Kobza et al., 2004; Magalhaes et al., 2007). However, population control may be more complex at these pools during dry periods due to isolation and crowding (Snodgrass et al., 1996; Chick et al., 2004). For example, fish must tolerate oxygen and nutrient depletion, high susceptibility to predation and diseases, and intra and inter-specific competition (De Angelis et al., 1997; Turner et al., 1999; Loftus, Eklund, 1994; Taylor et al., 2001; Trexler et al., 2001; Gawlik, 2002; Kobza et al., 2004; Ruetz et al., 2005). For this reason, the abundance of species habiting in widely varying environments depends on the duration of dry periods and the ability of species to persist harsh conditions. Although RSKB wetland experienced high variation in the hydrological regime and an extended dry period, our results indicated that species richness was constant over time, suggesting that species inhabiting this wetland are adapted to persist in highly fluctuating hydrological conditions. Species composition and rank abundances that stayed essentially the same over time in face of major environmental variation have been reported in Mediterranean-type streams (Moyle, Vondracek, 1985; Magalhaes et al., 2007) and other systems with harsh environmental conditions (Matthews, 1986; Eby et al., 2003; Mattews, Marsh-Mattews, 2003). This is consistent with habitat template theory that states the sequential seasonal and highly variable floods and drying events are primary landscape filters that reduce the species pool to those evolutionarily adapted to cope with the prevailing harsh environmental patterns (Southwood, 1977; Poff et al., 1997).

However, despite the observation that the studied species were resistant and resilient in some extent to the occurrence of relatively long dry periods, there was some indication that stronger and more enduring effects would probably have occurred if the dry period had lasted for a few more years, as it might be expected under a scenario of increasing dryness.

In summary, the results of this study highlight the importance to study the abundance responses of species at local and regional scales, in order to identify variations in life-history strategies which can reflect local adaptations of species to hydrological changes, which are needed to understand and predict the responses of fish communities to their environment. It is also important to continue monitoring fish responses in order to identify the most susceptible species to future climate change on these ecosystems.

\section{Acknowledgments}

This research was financed jointly by Universidad Nacional Autónoma de México (UNAM) fundings through the Programa de Apoyo a Proyectos de Investigación e Innovación Tecnológica (PAPIIT), Project number IN230007 and Secretaria del Medio ambiente y Recursos Naturales-Consejo Nacional de Ciencia y Tecnología (SEMARNAT-CONACyT) COI-2002-082. LHEV thanks to CONACyT for the scholarship No. 165043 granted for $\mathrm{PhD}$ studies. We thank to RBSK park rangers for field help and support, as well as the Comisión Nacional de Áreas Naturales Protegidas (CONANP) and anonymous reviewers for the useful comments provided.

\section{References}

Agostinho AA, Gomes LC, Veríssimo S, Okada EK. Flood regime, dam regulation and fish in the Upper Paraná River: effects on assemblage attributes, reproduction and recruitment. Rev Fish Biol Fish. 2004; 14(1):11-19.

Blanck A, Lamouroux N. Large-scale intraspecific variation in life-history traits of European freshwater fish. J Biogeogr. 2007; 34(5):862-75.

Blanck A, Tedesco PA, Lamouroux N. Relationships between life-history strategies of European freshwater fish species and their habitat preferences. Freshwater Biol. 2007; 52(5):843-59.

Chick JH, Ruetz CR, III, Trexler JC. Spatial scale and abundance patterns of large fish communities in freshwater marshes of the Florida Everglades. Wetlands. 2004; 24(3):652-64.

Cochran-Biederman JL, Winemiller KO. Relationships among habitat, ecomorphology and diets of cichlids in the Bladen River, Belize. Environ Biol Fish. 2010; 88(2):143-52.

Coops H, Beklioglu M, Crisman TL. The role of waterlevel fluctuactions in shallow lake ecosystems-workshop conclusions. Hydrobiologia. 2003; 506(1):23-27.

DeAngelis DL, Loftus WF, Trexler JC, Ulanowicz RE. Modeling fish dynamics and effects of stress in a hydrologically pulsed ecosystem. J Aquat Ecosyst Stress Recovery. 1997; 6(1):1-13.

DeAngelis DL, Trexler JC, Cosner C, Obaza A, Jopp F. Fish population dynamics in a seasonally varying wetland. Ecol Modell. 2010; 221(8):1131-37.

DeAngelis DL, Trexler JC, Loftus WF. Life history trade-offs and community dynamics of small fishes in a seasonally pulsed wetland. Can J Fish Aquat Sci. 2005; 62(4):781-90.

Eby LA, Fagan WF, Minckley WL. Variability and dynamics of a desert stream community. Ecol Appl. 2003; 13(6):1566-79.

Escalera-Vázquez LH, Zambrano L. The effect of seasonal variation in abiotic factors on fish community structure in temporary and permanent pools in a tropical wetland. Freshwater Biol. 2010; 55(12):2557-69.

Franssen NR, Gido KB, Guy CS, Tripe JA, Shrank SJ, Strakosh TR, Bertrand KN, Franssen CM, KL Pitts, Paukert CP. Effects of floods on fish assemblages in an intermittent prairie stream. Freshwater Biol. 2006; 51(11):2072-86. 
Gawlik DE. The effects of prey availability on the numerical response of wading birds. Ecol Monogr. 2002; 72(3):329-46.

Gomes LC, Agostinho AA. Influence of the flooding regime on the nutritional state and juvenile recruitment of the curimba, Prochilodus scrofa, Steindachner, in upper Paraná River, Brazil. Fish Manag Ecol. 1997; 4(4):263-74.

Greenfield DW, Thomerson JE, editors. Fishes of the Continental Waters of Belize. Gainesville: University Press of Florida; 1997.

Gubiani EA, Gomes LC, Agostinho AA, Okada EK. Persistence of fish populations in the upper Paraná River: effects of water regulation by dams. Ecol Freshw Fish. 2007; 16(2):191-97.

Hinojosa-Garro D, Arceo-Gómez J, Zambrano L, EscaleraVázquez LH. Fish diet composition in permanent and semi-permanent pools in tropical wetlands of the Yucatán Peninsula. Neotrop Ichthyol. 2013; 11(4):881-90.

King AJ, Humphries P, Lake PS. Fish recruitment on floodplains: the roles of patterns of flooding and life history characteristics. Can J Fish Aquat Sci. 2003; 60(7):773-86.

Kobza RM, Trexler JC, Loftus WF, Perry SA. Community structure of fishes inhabiting aquatic refuges in a threatened Karst wetland and its implications for ecosystem management. Biol Conserv. 2004; 116(2):153-65.

Lamouroux N, Poff NL, Angermeier PL. Intercontinental convergence of stream fish community traits along geomorphic and hydraulic gradients. Ecology. 2002; 83(7):1792-1807.

Legendre P, Gallagher ED. Ecologically meaningful transformations for ordination of species data. Oecologia. 2001; 129(2):271-80.

Legendre P, Legendre L. Numerical ecology. Amsterdam: Elsevier; 1998.

Littell RC, Milliken GA, Stroup WW, Wolfinger RD. SAS System for mixed models. Cary: SAS Institute Inc.; 1996.

Loftus WF, Eklund AM. Long-term dynamics of an Everglades small-fish assemblage. In: Davis SM, Ogden JC, editors. Everglades: the Ecosystem and its Restoration. Boca Raton: CRC Press; 1994. p.461-483.

Lytle DA, Poff NL. Adaptation to natural flow regimes. Trends Ecol Evol. 2004; 19(2):94-100.

Magalhaes MF, Beja P, Schlosser IJ, Collares-Pereira MJ. Effects of multi-year droughts on fish assemblages of seasonally drying Mediterranean streams. Freshwater Biol. 2007; 52(8):1494-510.

Magoulick DD, Kobza RM. The role of refugia for fishes during drought: a review and synthesis. Freshwater Biol. 2003; 48(7):1186-98.

Matthews WJ. Fish faunal structure in an Ozark stream: stability, persistence and a catastrophic flood. Copeia. 1986; (2):388-97.

Matthews WJ, Marsh-Matthews E. Effects of drought on fish across axes of space, time and ecological complexity. Freshwater Biol. 2003; 48(7):1232-53.

McKaye KR. Seasonality in habitat selection by the gold color morph of Cichlasoma citrinellum and its relevance to sympatric speciation in the family Cichlidae. Environ Biol Fishes. 1980; 5(1):75-78.
Meffe GK, Snelson FF, Jr., editors. Ecology and evolution of livebearing fishes (Poeciliidae). Englewood Cliffs: Prentice Hall; 1989.

Miller RR, Minckley WL, Norris ST, editors. Freshwater Fishes of Mexico. Chicago; London: University of Chicago Press; 2005.

Mims MC, Olden JD. Life history theory predicts fish assemblage response to hydrologic regimes. Ecology. 2012; 93(1):35-45.

Mims MC, Olden JD, Shattuck ZR, Poff NL. Life history trait diversity of native freshwater fishes in North America. Ecol Freshw Fish. 2010; 19(3):390-400.

Mitsch WJ, Gosselink JG, Anderson CJ, Zhang L, editors.Wetland Ecosystems. Hoboken : John Wiley \& Sons, Inc.; 2009.

Moyle PB, Vondracek B. Persistence and structure of the fish assemblage in a small California stream. Ecology. 1985; 66(1):1-13.

Nelson JS, Crossman EJ, Espinosa-Perez H, Findley LT, Gilbert CR, Lea RN, Williams JD, editors. Common and scientific names of fishes from the United States, Canada, and Mexico. Bethesda: American Fisheries Society; 2004. (American Fisheries Society Special Publication; 34).

Obaza A, DeAngelis DL, Trexler JC. Using data from an encounter sampler to model fish dispersal. J Fish Biol. 2011; 78(2):495513.

Oksanen J, Blanchet FG, Kindt R, Legendre P, Minchin PR, O'Hara RB, Simpson GL, Solymos P, Stevens MHH, Szoecs E, Wagner H. Vegan: Community ecology package v. 2.0-2; 2013. Available from: http://cran.r-project.org/web/packages/ vegan/index.html

Olden JD, Kennard MJ. Intercontinental comparison of fish life history strategies along a gradient of hydrologic variability. Am Fish Soc Symp. 2010; 73:83-107.

Poff NL, Allan JD, Bain MB, Karr JR, Prestegaard KL, Richter BD, Sparks RE, Stromberg JC. The Natural Flow Regime: A paradigm for river conservation and restoration. BioScience. 1997; 47(11):769-84.

R Development Core Team. R: a language and environment for statistical computing [Computer software manual - Internet]. Vienna: R Foundation for Statistical Computing; 2014. Available from: https://www.rproject.org/

Richter BD, Baumgartner JV, Powell J, Braun DP. A method for assessing hydrologic alteration within ecosystems. Conserv Biol. 1996; 10(4):1163-74.

Rochet M. A comparative approach to life-history strategies and tactics among four orders of teleost fish. ICES J Mar Sci. 2000; 57(2):228-39.

Rose KA, Cowan JH, Jr. Predicting fish population dynamics: compensation and the importance of site-specific considerations. Environ Sci Policy. 2000; 3(S1):433-43.

Ruetz CR, III, Trexler JC, Jordan F, Loftus WF, Perry SA. Population dynamics of wetland fishes: spatio-temporal patterns synchronized by hydrological disturbance? J Anim Ecol. 2005; 74(2):322-32.

Snodgrass JW, Bryan ALJ, Jr., Lide RF, Smith GM. Factors affecting the occurrence and structure of fish assemblages in isolated wetlands of the upper coastal plain, U.S.A. Can J Fish Aquat Sci. 1996; 53(2):443-54. 
Southwood TRE. Habitat, the templet for ecological strategies? J Anim Ecol. 1977; 46(2):337-65.

Taylor RC, Trexler JC, Loftus WF. Separating the effects of intraand interspecific age-structured interactions in an experimental fish assemblage. Oecologia. 2001;127(1):143-52.

Tedesco P, Hugueny B. Life history strategies affect climate based spatial synchrony in population dynamics of West African freshwater fishes. Oikos. 2006; 115(1):117-27.

Tedesco PA, Hugueny B, Oberdorff T, Dürr HH, Mérigoux S, Mérona B. River hydrological seasonality influences life history strategies of tropical riverine fishes. Oecologia. 2008; 156(3):691-702.

Ter Braak CJF, Verdonschot PFM. Canonical correspondence analysis and related multivariate methods in aquatic ecology. Aquat Sci. 1995; 57(3):255-89.

Trexler JC, Loftus WF, Jordan F, Chick JH, Kandl KL, McElroy TC, Bass OL, Jr. Ecological scale and its implications for freshwater fishes in the Florida Everglades. In: Porter JW, Porter KG, editors. The Everglades, Florida Bay, and coral reefs of the Florida keys: an ecosystem sourcebook. Boca Raton: CRC Press; 2001. p.153-181.

Turner AM, Trexler JC, Jordan CF, Slack SJ, Geddes P, Chick JH, Loftus WF. Targeting ecosystem features for conservation: Standing crops in the Florida Everglades. Conserv Biol. 1999; 13(4):898-911.
Vila-Gispert A, Moreno-Amich R, García-Berthou E. Gradients of life history variation: an intercontinental comparison of fishes. Rev Fish Biol Fish. 2002; 12(4):417-27.

Wantzen KM, Rothhaupt KO, Mörtl M, Cantonati M, G-Tóth L, Fischer P. Ecological effects of water-level fluctuations in lakes: an urgent issue. Hydrobiologia. 2008; 613(1):1-4.

Winemiller KO. Patterns of variation in life history among South American fishes in seasonal environments. Oecologia. 1989; 81(2):225-41.

Winemiller KO. Life history strategies, population regulation, and implications for fisheries management. Can J Fish Aquat Sci. 2005; 62(4):872-85.

Winemiller KO, Rose KA. Patterns of life-history diversification in North American fishes: implications for population regulation. Can J Fish Aquat Sci. 1992; 49(10):2196-218.

Zambrano L, Vázquez-Domínguez E, García-Bedoya D, Loftus WF, Trexler JC. Fish community structure in freshwater karstic waterbodies of the Sian Ka'an Reserve in Yucatán península, México. Ichthyol Explor Freshw. 2006; 17(3):193-206.

Submitted September 20, 2016 Accepted April 28, 2017 by Lilian Casatti 
